\title{
A new genus and species of the longicorn beetle tribe Tillomorphini Lacordaire, 1868 (Coleoptera: Cerambycidae) from India
}

\author{
Новые род и вид жкуков-дровосеков трибы Tillomorphini \\ Lacordaire, 1868 (Coleoptera: Cerambycidae) из Индии
}

\author{
Alexandr I. Miroshnikovi,2, Tomáš Tichý' \\ А.И. Мирошников ${ }^{1,2}$, Т. Тихий
}

\footnotetext{
${ }^{1}$ Russian Entomological Society, Krasnodar, Russia. E-mail: miroshnikov-ai@yandex.ru

${ }^{1}$ Русское энтомологическое общество, Краснодар, Россия.

2 Sochi National Park, Moskovskaya str., 21, Sochi, Krasnodar region 354002, Russia

${ }^{2}$ Сочинский национальный парк, ул. Московская, 21, Сочи, Краснодарский край 354000, Россия.

3 Technical University of Ostrava, Sokolska tr. 33, Ostrava 70121, Czech Republic
}

KEY WORDS: Coleoptera, Cerambycidae, Tillomorphini, new genus and species, southern India.

КЛЮЧЕВЫЕ СЛОВА: Coleoptera, Cerambycidae, Tillomorphini, новые род и вид, южная Индия.

ABSTRACT. Indapiodes bifasciatus gen.n., sp.n., a new member of the tribe Tillomorphini, is described from southern India.

РЕЗЮМЕ. Описывается новый представитель трибы Tillomorphini — Indapiodes bifasciatus gen.n., sp.n. из южной Индии.

\section{Introduction}

In 2014, during the second author's visit to the National Museum of Natural History, Smithsonian Institution, Washington D.C., U.S.A. (USNM), a representative of the longicorn beetle tribe Tillomorphini Lacordaire, 1868 was found among unidentified samples coming from southern India. This new cerambycid appears to actually belong to a new genus and species, both described below. The holotype is kept in the USNM collection.

\section{Taxonomy}

Indapiodes Miroshnikov et Tichý, gen.n. sp.n.

Type species: Indapiodes bifasciatus Miroshnikov et Tichý,

DIAGNOSIS. The new genus shows the peculiar combination of characters that clearly makes it different from all other Oriental genera of the tribe Tillomorphini. In its habitus, a vague similarity is observed to the North African Pseudomyrmecion Bedel, 1885.
DESCRIPTION. Body small, moderately compressed. Head wide, well-developed; frons clearly transverse, distinctly convex; eyes without emargination, with a completely reduced dorsal lobe and evident, but not large ocelli, moderately convex; genae clearly shorter than transverse diameter of an eye; temples long, widely rounded and strongly narrowed backwards; palpi short; antennae slender, filiform, moderately long, their bases widely spaced; antennal tubercles poorly-developed, flattened; antennomere 1 strongly curved, longest.

Pronotum strongly longitudinal, much narrower at base than at apex, as in Figs 1-2; with distinct, widely rounded, lateral tubercles; very clearly deeper constricted in front of base than in apical one-third; strongly convex, as in Fig. 3; on disc partly with a rough sculpture.

Elytra strongly elongate and strongly broadened towards apex, pear-shaped, as in Fig. 1; humeri barely expressed; apex slightly emarginate, apical external angle widely rounded, sutural angle well-expressed, subrectangular; on disc moderately convex; behind scutellum clearly impressed about twice the latter's length in the area of suture; monochrome, without inflated fragments of surface in the form of narrow light fascia, but with fasciae of recumbent light setae.

Prosternum without deep punctures (on the contrary, the presence of deep, often coarse punctures in the male is highly characteristic of many tillomorphine genera), in profile very strongly curved in apical part, as in Fig. 3; procoxal cavities closed posteriorly, the part of prosternum closing the cavities posteriorly being rather wide; prosternal process moderately narrow between coxae, strongly broadened towards apex behind the middle; mesosternal process between coxae clearly narrower than prosternal process; metasternum relatively short, slightly or significantly shorter than mesostrenum and first (visible) sternite, respectively; first (visible) sternite

How to cite this article: Miroshnikov A.I., Tichý T. 2018. A new genus and species of the longicorn beetle tribe Tillomorphini Lacordaire, 1868 (Coleoptera: Cerambycidae) from India // Russian Entomol. J. Vol.27. No.2. P.153-155. doi: 10.15298/rusentj.27.2.05 


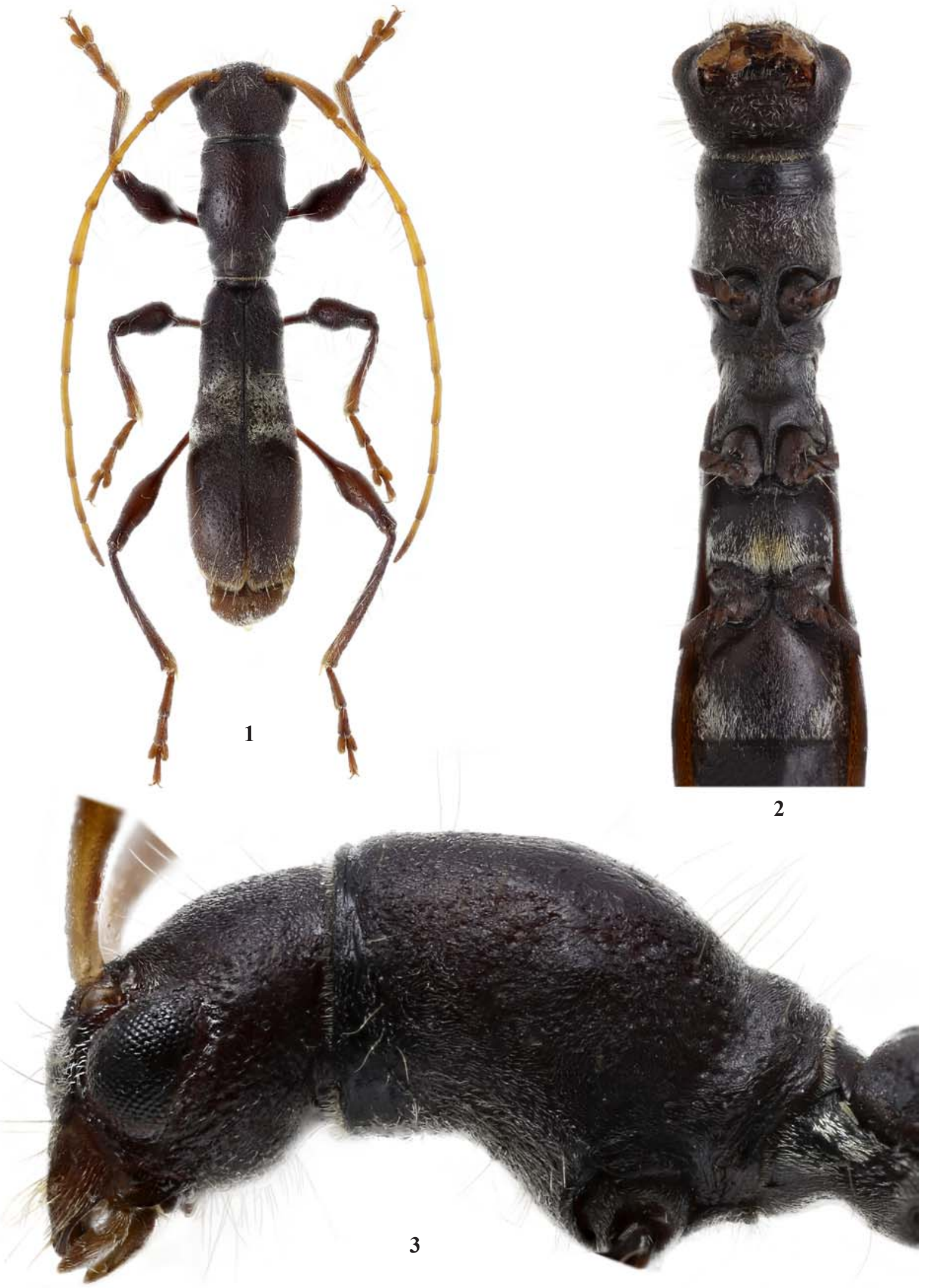

Figs 1-3. Indapiodes bifasciatus gen.n., sp.n.: 1 - habitus, dorsal view; 2 - body, ventral view; 3 - head and prothorax, lateral view. Pис. 1-3. Indapiodes bifasciatus gen.n., sp.n.: 1 - общий вид, сверху; 2 - тело, снизу; 3 - голова и переднегрудь, сбоку. 
very clearly shorter than all following (visible) sternites combined; metepisterna almost completely concealed under the elytra.

Legs rather long, thereby metafemora slightly reaching beyond apex of elytra; femora strongly claviform.

ETYMOLOGY. The name of the new genus is associated with its provenance (India) and the peculiar shape of the elytra (attion - apion, meaning a pear in Ancient Greek).

COMPOSITION. The new genus includes a single species. India.

DISTRIBUTION. So far this genus is known only from

REMARKS. According to the latest listing [Kariyanna et al., 2017], only five genera of the tribe Tillomorphini are presently known to occur in India. In this regard, another new genus is an important addition to such a small tribe in the fauna of India.

Indapiodes bifasciatus Miroshnikov et Tichý, sp.n. Figs 1-3.

MATERIAL. Holotype, or (USNM), India, Andhra Pradesh, Hyderabad, 17-18.08.1967, leg. K.E. Gibson.

DESCRIPTION. Male. Body length $8.0 \mathrm{~mm}$, humeral width $1.2 \mathrm{~mm}$. Reddish dark brown; tibiae partly and tarsi reddish; femora partly red and dark red tones; antennae almost completely yellow, with darker antennomere 1 and apicies of antennomeres 5-11.

Head at eye level slightly wider than pronotum at level of lateral tubercles; with an unclear obliterated sculpture dorsally, but with a distinctly scabrous sculpture mainly in area of temples and ventrally; shortest distance between antennal cavities about equal to longitudinal diameter of an eye; genae slightly shorter than last segment of maxillary palpi; last segment of both labial and maxillary palpi axeshaped; antennae reaching beyond apex of elytra by last antennomere; length ratio of antennomeres $1-11,48: 7: 31$ $: 31: 33: 31: 31: 30: 28: 28: 30$; antennomere 2 barely longitudinal.
Pronotum 1.54 times as long as width, at apex 1.3 times as long as at base; with scabrous sculpture and individual, heterogeneous, irregular, coarse and rough, but not too deep punctures.

Scutellum narrowed towards apex, triangular, rounded apically.

Elytra 4 times as long as width at base level with scutellum apex, while their maximum width 2.2 times greater than that at the very base; with a rough, more or less regular, sparse puncturation decreasing from base towards apex; with two fasciae of dense, recumbent, silvery setae in middle part.

Prosternum with transverse gentle folds near apex; metasternum with a tuft of recumbent and partly suberect, dense, yellowish setae in middle area of apical part, as in Fig. 2; last (visible) sternite with a clear broad emargination.

Body, antennae and legs with long and very long, erect, sparse, thin, light setae.

ETYMOLOGY. The name of the new species is associated with the peculiar setation of its elytra forming two clear and light fasciae.

DISTRIBUTION. Southern India.

ACKNOWLEDGEMENTS. We are very grateful to Steven W. Lingafelter, the then Keeper at the USNM, who kindly arranged on loan the material under his care, to Kirill V. Makarov (Moscow Pedagogical State University, Russia) for having rendered his great help in the preparation of the photographs. Our special thanks to Alexandr F. Emeljanov and Boris A. Korotyaev (Zoological Institute of the Russian Academy of Sciences, St. Petersburg, Russia) for their advice concerning some nomenclatural issues.

\section{References}

Kariyanna B., Mohan M., Gupta R., Vitali F. 2017. The checklist of longhorn beetles (Coleoptera: Cerambycidae) from India // Zootaxa. Vol.4345. No.1. P.1-317. 